\title{
Quantitative Studies of Febrile Tolerance and Levels of Specific Antibody Evoked by Bacterial Endotoxin*
}

\author{
John H. Mulholland, Sheldon M. Wolff, $\dagger$ Anne L. Jackson, $\ddagger$ ANd \\ Maurice Landy \\ (From the Laboratories of Clinical Investigations and Immunology, National Institute \\ of Allergy and Infectious Diseases, Bethesda, Md.)
}

A series of endotoxin injections, either in constant or progressively increasing increments, will induce a state of refractoriness termed endotoxin tolerance. Resistance to the febrile effect of endotoxin is believed to be of short duration, disappearing within 3 weeks (2). Inasmuch as bacterial endotoxins are potent $\mathrm{O}$ antigens and give rise to the production of specific antibody, early workers considered the possibility of a correlation between increased antibody levels and diminished febrile response (3). However, Morgan was unable to discern a relationship between the magnitude of febrile reactivity and the levels of $\mathrm{O}$ agglutinins attained in rabbits given typhoid endotoxin (4).

Subsequently, Beeson sought, without success, to transfer tolerance passively with serum of rabbits that had been rendered refractory (5). $\mathrm{He}$ also reported that the tolerant state was accompanied by increased activity of the reticuloendothelial system (RES). His finding that febrile tolerance was abolished by "blockade" of the RES with thorium dioxide (Thorotrast) attested to the major role of the RES in this situation (6). These findings constituted the major evidence in support of the concept that humoral mechanisms play no role in tolerance. Nonetheless, compelling data to the contrary had been obtained by Creech,

* Submitted for publication August 20, 1964; accepted February 15, 1965.

Presented in part at the meeting of the American Association of Immunologists, Chicago, Ill., April 17, 1964 (1).

$\dagger$ Address requests for reprints to Dr. Sheldon M. Wolff, Laboratory of Clinical Investigations, National Institute of Allergy and Infectious Diseases, National Institutes of Health, Bethesda, Md. 20014.

$\ddagger$ Recipient of National Institutes of Health postdoctoral training grant 5TIAI 182. Present address: Department of Microbiology, Georgetown University School of Medicine, Washington, D. C.
Hankwitz, and Wharton, who were able to demonstrate protection against lethality with serum from endotoxin-treated rabbits and mice (7).

Several recent developments have led to a revival of interest in the possibility that immunologic mechanisms may be implicated in endotoxin tolerance: $a$ ) the demonstration that the passive transfer of serum from tolerant hosts confers on recipients a reduction in pyrogenic response (8); $b$ ) the discovery that RES-blockaded tolerant rabbits retain a significant degree of tolerance when compared with either blockaded (9) or nonblockaded normals (10); and $c$ ) evidence that two types of immunoglobulins ( $7 \mathrm{~S}$ and $19 \mathrm{~S}$ ) are produced in response to stimulation with these somatic antigens (11). $19 \mathrm{~S}$ macroglobulins are potent opsonins and possess complement-fixing activity (12). Since these capabilities are likely to be implicated in host resistance to endotoxin, the type of antibody evoked in the production of tolerance could be important.

Although frequent reference has been recently made to the involvement of immunologic factors, there has been an absence of information on serum antibody measurements in animals rendered refractory to the pyrogenic effects of endotoxin. Furthermore, there is a paucity of quantitative data as regards the rate at which tolerance is lost. Accordingly, studies were undertaken to determine by quantitative methods the pyrogenic reactivity and concomitant levels of specific antibody during a prolonged period in rabbits that had been rendered tolerant by single or multiple injections of bacterial endotoxin.

\section{Methods}

Rabbits

More than 300 New Zealand albino rabbits of both sexes, weighing approximately $2 \mathrm{~kg}$, from the same colony (National Institutes of Health) were used. Ani- 
mals were housed in air-conditioned quarters and tested in the same room.

\section{Recording of temperature}

Temperatures (degrees Centigrade) were monitored with thermistors connected to a recording telethermometer ${ }^{1}$ and inserted 4 to 6 inches into the rectum. On the day before testing, rabbits were trained for 6 to 8 hours in wooden stocks with loosely fitting collars. To insure a steady base line on the day of testing, temperatures were recorded for at least 1 hour before injection; animals with temperatures that varied more than $0.2^{\circ} \mathrm{C}$ or were below 38.5 or above $39.9^{\circ} \mathrm{C}$ were excluded. $\mathrm{Fe}$ brile responses were plotted on 1 - by 1 -inch. standard graph paper; ${ }^{2} 1$ hour and 1 degree each equaled 1 inch. The area in centimeters squared, fever index (FI), under a 5-hour fever curve, was measured with a compensating polar planimeter. ${ }^{3}$ Data were recorded as the mean FI of four or more animals.

\section{Endotoxin}

A purified endotoxin derived from Salmonella enteritidis by the aqueous-ether procedure was used throughout (13). The endotoxin, prepared in concentrated stock solution ( 0.5 to $1 \mathrm{mg}$ per $\mathrm{ml}$ ) by adding sterile phosphate-buffered saline $(\mathrm{pH} 7.4)$ and agitating on a rotating machine, was stored at $-20^{\circ} \mathrm{C}$ in pyrogen-free vials. Immediately before use the stock solution was defrosted and diluted appropriately with saline. The endotoxin was injected in 1-ml quantities into a marginal ear vein. Sterile, pyrogen-free disposable needles and syringes were used throughout.

\section{Collection of serum}

Blood specimens for serologic tests were obtained in 5- to $10-\mathrm{ml}$ samples from marginal ear veins. Animals were bled before the first injection of endotoxin and on the afternoon before the day they were to be challenged. Individual samples were allowed to clot at room temperature, and the serum was separated by centrifugation. The serum from each animal and, in most instances, pools from each group of rabbits were distributed in 3- to $10-\mathrm{ml}$ amounts and stored at $-70^{\circ} \mathrm{C}$.

\section{Antibody assays}

All antibody assays were performed on pooled sera.

Bactericidal activity. In the presence of complement, antibody is capable of killing certain strains of Enterobacteriaceae (14). Serum bactericidal activity was assayed by adding $0.2 \mathrm{log}$ dilutions of the test serum to an equal volume of the complement source (precolostral calf serum). To each of these mixtures was added 100 viable Salmonella typhosa 0901 ; after incubation at $37^{\circ} \mathrm{C}$ for 60 minutes, plating, and overnight incubation, colonies were enumerated, and antibody activity was expressed as

\footnotetext{
1 Yellow Springs Instrument Co., Yellow Springs, Ohio.

2 Keuffel and Esser (12-5265), Hoboken, N. J.

${ }^{3} \mathrm{Keuffel}$ and Esser (4242), Hoboken, N. J.
}

the reciprocal of the serum dilution calculated to kill $50 \%$ of the inoculum $\left(\mathrm{SD}_{50}\right)$.

Hemagglutinating antibody. Hemagglutinating antibody was determined by mixing $0.2 \mathrm{ml}$ of doubling dilutions of serum with an equal volume of sheep erythrocytes previously coated with alkali-treated Salmonella enteritidis endotoxin (10 $\mu \mathrm{g}$ antigen per $\mathrm{ml} 1 \%$ erythrocytes). Agglutination was read after incubation for 2 hours at $37^{\circ} \mathrm{C}$ followed by 18 hours at $4^{\circ} \mathrm{C}$. The titer was expressed as the reciprocal of the final serum dilution giving grossly visible agglutination.

Bentonite flocculation. Serum antibody was measured by coating bentonite particles with the homologous endotoxin and observing flocculation by serial twofold dilutions of the sera (15).

Bacterial agglutination. The agglutination reagent employed was a heat-killed $\left(2\right.$ hours at $100^{\circ} \mathrm{C}$ ) and washed suspension of $S$. enteritidis adjusted to a concentration of $1 \times 10^{9}$ organisms per $\mathrm{ml}$. To $0.25-\mathrm{ml}$ volumes of doubling dilutions of test sera, distributed in Kahn tubes, was added an equal volume of the bacterial suspension, and the tubes were incubated for 18 hours in a water bath at $52^{\circ} \mathrm{C}$. Agglutination was read macroscopically, and the highest serum dilution giving unequivocal agglutination was recorded as the titer.

Quantitative precipitin tests. To $0.25-\mathrm{ml}$ samples of test serum was added 5.0 to $40 \mu \mathrm{g}$ of $S$. enteritidis somatic antigen. The mixtures were incubated for 2 hours at $37^{\circ} \mathrm{C}$ followed by 2 days at $4^{\circ} \mathrm{C}$, centrifuged supernatant fluids removed, and the resultant precipitates washed twice with cold saline. Supernatants were examined for free antigen; the presence of antigen was taken as evidence that essentially all the antibody present, capable of combining with antigen, was in the precipitate. The largest quantity of antigen employed $(40 \mu \mathrm{g})$ contributed so little protein that no correction for antigen $\mathrm{N}$ was required. Analyses for antibody protein in immune precipitates were made (16).

Serum fractionation. Pooled sera were fractionated by gel filtration on Sephadex G-200 (17) and by ultracentrifugation in 10 to $37 \%$ linear sucrose gradients (18). Individual samples from the macroglobulin and $7 \mathrm{~S}$ fractions were diluted at $0.5 \mathrm{log}$ intervals and assayed for bactericidal activity.

\section{Results}

\section{Characteristics of febrile tolerance and antibody} response to a series of injections of endotoxin. To further define the magnitude and duration of tolerance, the following experiments were performed. Tolerance was established in 110 normal rabbits by a series of nine daily intravenous injections of $0.25 \mu \mathrm{g}$ of endotoxin. On the day following the last injection and at intervals thereafter, separate groups of three to eight rabbits were challenged with doses of endotoxin ranging from 0.25 to $250 \mu \mathrm{g}$. The dose of $0.25 \mu \mathrm{g}$ was administered at 


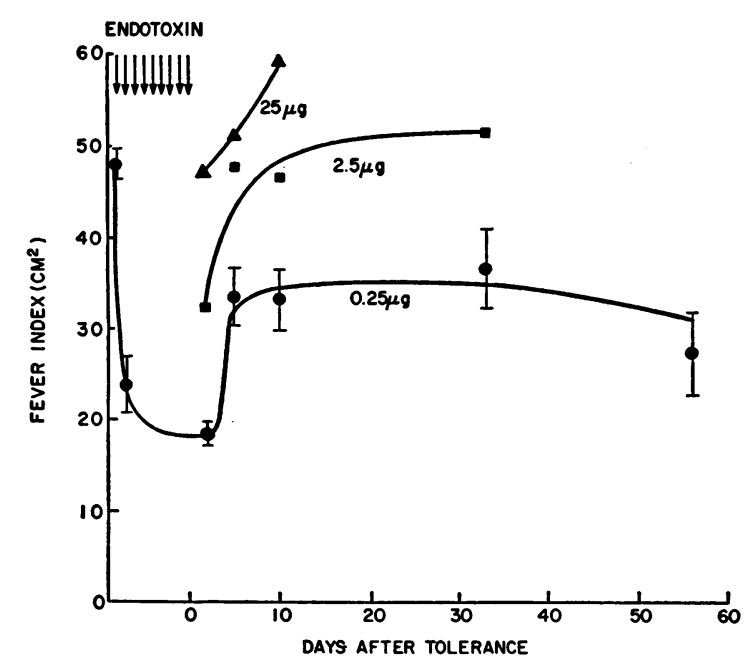

Fig. 1. Development and duration of Febrile tolERANCE TO A SERIES OF NINE DAILY INJECTIONS (ARROWS) of $0.25 \mu \mathrm{G}$ of ENDOTOXIN. At varying time intervals thereafter animals were challenged with $0.25,2.5$, or 25 $\mu \mathrm{g}$. Mean fever index \pm standard error plotted for $0.25-$ $\mu \mathrm{g}$ challenge. Response of normal rabbits to $2.5 \mu \mathrm{g}$ is $52.9 \pm 4.2 \mathrm{~cm}^{2}$. See text.

each of the test intervals; higher doses were employed at selected times. Normal rabbits were tested simultaneously with $0.25 \mu \mathrm{g}$ to provide direct comparative data.

On the day following the final injection, marked refractoriness to the febrile effects of endotoxin was apparent at each challenge dose employed (day 1, Figure 1). At the next test interval, 5 days later, febrile reactivity to $0.25 \mu \mathrm{g}$ had increased significantly when compared to the responses on the day following the series of injections ( $p<0.01, t$ test); however, when the re- sponse at 5 days was compared to the responses of normals, appreciable tolerance to the $0.25-\mu \mathrm{g}$ dose was still apparent $(p<0.01)$. This state of tolerance was maintained throughout the duration of the experiment (56 days, Figure 1) and in each instance was significantly different from controls $(p<0.01)$. Another group of normal rabbits, made tolerant in the same way, and challenged 5 or 10 days later with $0.25 \mu \mathrm{g}$, confirmed the early loss of tolerance. Since the results were similar to those noted in the initial experiment, they are included in the data depicted in Figure $1 .^{4}$

As would be expected, the early decline in tolerance was most evident at the higher challenge doses. The responses to the $250-\mu \mathrm{g}$ dose, 1 and 5 days following the course of injections, are not included in Figure 1, inasmuch as the reactivity to this relatively massive amount of endotoxin was at the very extreme limits of responsiveness (FI > 60 ). On day 10, animals tested with $25 \mu \mathrm{g}$ also reacted maximally. Since in these experiments normal rabbits given 25 or $250 \mu \mathrm{g}$ of this $S$. enteritidis endotoxin preparation displayed profound shock, hypothermia, and death, the fact that these rabbits developed febrile responses in itself constitutes evidence of a tolerant state. The $25-\mu \mathrm{g}$ challenge dose was lethal for six of seven normal rabbits; in contrast, only one of eleven tolerant

4 In an additional experiment, 8 of a group of $17 \mathrm{rab}$ bits were rendered tolerant as previously described. Sixty-three days later all animals were challenged with $0.25 \mu \mathrm{g}$ of endotoxin. The group previously made tolerant had mean fever indexes significantly lower than the controls $(p<0.01)$, thus substantiating the persistence of tolerance noted in the first experiment.

TABLE I

Antibody levels in rabbits following the development of endotoxin tolerance

\begin{tabular}{|c|c|c|c|c|c|}
\hline \multirow[b]{2}{*}{$\begin{array}{l}\text { Animal } \\
\text { status }\end{array}$} & \multicolumn{4}{|c|}{ Antibody titer* } & \multirow[b]{2}{*}{$\begin{array}{c}\text { Antibody } \\
\text { nitrogen }\end{array}$} \\
\hline & $\begin{array}{l}\text { Bactericidal } \\
\left(\mathrm{SD}_{60}\right)\end{array}$ & $\begin{array}{c}\text { Bacterial } \\
\text { agglutination }\end{array}$ & $\begin{array}{c}\text { Passive } \\
\text { hemagglu- } \\
\text { tination }\end{array}$ & $\begin{array}{l}\text { Bentonite } \\
\text { flocculation }\end{array}$ & \\
\hline & & & & & $\mu g / m l$ \\
\hline Normal & $80-500$ & $<5$ & $<5$ & $<2$ & $<2$ \\
\hline $1 \dagger$ & 280,000 & 320 & 1,280 & 1,024 & 50.4 \\
\hline 5 & 160,000 & 320 & 1,280 & 512 & 41.6 \\
\hline 10 & 100,000 & 160 & 640 & 512 & 35.2 \\
\hline 18 & 45,000 & 80 & 320 & 128 & 25.6 \\
\hline 24 & 23,000 & 80 & 160 & 128 & 28.8 \\
\hline 33 & 14,000 & 40 & 160 & 64 & 28.8 \\
\hline 56 & 12,500 & 40 & 160 & 64 & 16.0 \\
\hline
\end{tabular}

* Data derived from pooled sera and expressed as the reciprocals of the titers,

$\dagger$ Days after the last of nine daily injections of endotoxin. 


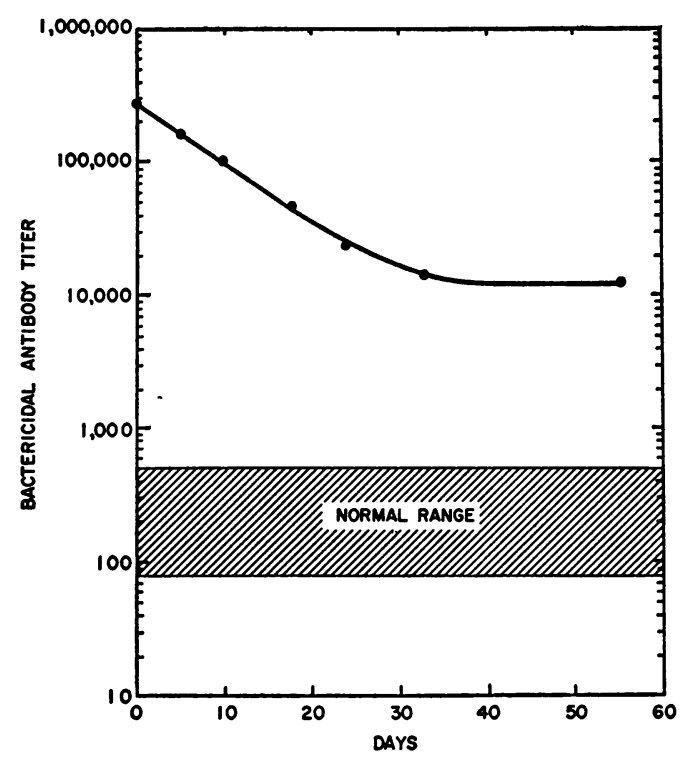

Fig. 2. DECline of BACTERICIDAL ANTIBOdy TITER FOLLOWING A SERIES OF NINE DAILY INJECTIONS OF $0.25 \mu \mathrm{G}$ OF ENDOTOXIN (day 0 is the first day after the series). Data derived from pooled sera and expressed as the reciprocals of the titers.

animals tested within 10 days died. In addition, by day 10 the $250-\mu \mathrm{g}$ dose proved lethal for two of three tolerant rabbits tested. The reactivity of animals tested with $2.5 \mu \mathrm{g}$ on day 5 was not significantly different from that of normal rabbits.

Pooled serum samples from 12 to 16 individual rabbits, obtained before challenge at each test interval, were assayed for specific antibody to the somatic antigen (endotoxin) of $S$. enteritidis ( $\mathrm{Ta}$ ble I). Of the five techniques employed only the bactericidal assay consistently disclosed the presence of antibody in normal sera (Table I). On the day following the series of injections the level of bactericidal antibody had risen approximately 1,000-fold (Table I). Thereafter, a progressive decline was evident by each of the methods except that of quantitative precipitation, which reflected a slower rate of decline. The rate of decay of bactericidal antibody was essentially exponential during the 30-day period following endotoxin treatment; thereafter, no further change was discernible (Figure 2).

Serum pools were subjected to gel filtration with Sephadex G-200 and to ultracentrifugation through sucrose density gradients; fractions containing macroglobulin and gamma globulin were assayed for specific antibody by the bactericidal procedure.
At the time of maximal tolerance antibody activity was confined to the macroglobulin fractions as had been observed previously (11). Twenty-four days later small amounts of antibody had appeared in the $7 \mathrm{~S}$ fractions. However, at the time the experiment was terminated ( 56 days), the amount of $7 \mathrm{~S}$ antibody remained low, whereas the macroglobulin fractions still contained more than $90 \%$ of the bactericidal antibody.

Characteristics of febrile tolerance and antibody response to a single injection of endotoxin. Most investigations of endotoxin tolerance have been based on its induction by a series of five to ten daily injections. Nonetheless, it has been recognized that animals receiving a single injection display diminished febrile response the following day (19). To obtain information on the duration and magnitude of the latter effect, after a single injection of $0.25 \mu \mathrm{g}$ of endotoxin, groups of 5 to 20 rabbits were rechallenged once with the same dose at intervals from 1 to 34 days. A marked reduction in febrile reactivity was noted 1 day later, and significant tolerance continued for the remainder of the experiment-34 days ( $p<0.01$ for each challenge interval) (Table II). To exclude the possibility that the results were peculiar to the endotoxin employed, similar experiments utilizing an Escherichia coli endotoxin were done that confirmed the above results.

As was to be expected, no significant increase in antibody was discernible until 48 to 72 hours

TABLE II

Antibody levels and altered febrile reactivity following a single injection of endotoxin

\begin{tabular}{|c|c|c|c|c|}
\hline \multicolumn{5}{|c|}{ Second endotoxin injection } \\
\hline \multirow{2}{*}{$\begin{array}{l}\text { Interval } \\
\text { after } \\
\text { initial } \\
\text { injection }\end{array}$} & \multirow[b]{2}{*}{ Fever index } & \multirow{2}{*}{$\begin{array}{l}\text { No. of } \\
\text { rabbits } \\
\text { tested }\end{array}$} & \multicolumn{2}{|c|}{ Antibody titer* } \\
\hline & & & $\begin{array}{l}\text { Bacteri- } \\
\text { cidal }\end{array}$ & $\begin{array}{c}\text { Ben- } \\
\text { tonite }\end{array}$ \\
\hline days & $\mathrm{cm}^{2}$ & & & \\
\hline 0 & $48.6 \pm 1.3 \dagger$ & $44 \ddagger$ & $<500$ & $<2$ \\
\hline 1 & $23.7 \pm 2.9$ & 20 & $<500$ & $<2$ \\
\hline 2 & $40.0 \pm 2.6$ & 16 & $<500$ & $<2$ \\
\hline 3 & $34.4 \pm 3.4$ & 7 & 2,500 & 2 \\
\hline 4 & $37.3 \pm 2.3$ & 13 & 17,850 & 16 \\
\hline 5 & $30.5 \pm 1.9$ & 8 & 31,250 & 32 \\
\hline 8 & $28.7 \pm 3.8$ & 6 & 25,700 & 64 \\
\hline 13 & $35.3 \pm 5.1$ & 6 & 12,500 & 8 \\
\hline 21 & $32.9 \pm 4.6$ & 5 & 4,600 & 4 \\
\hline 34 & $35.3 \pm 2.6$ & 8 & 8,100 & 8 \\
\hline
\end{tabular}

* Data derived from pooled sera and expressed as the reciprocals of the titers.

$\dagger$ Mean \pm standard error.

$\ddagger$ Febrile responses not obtained on all rabbits following the first injection. 


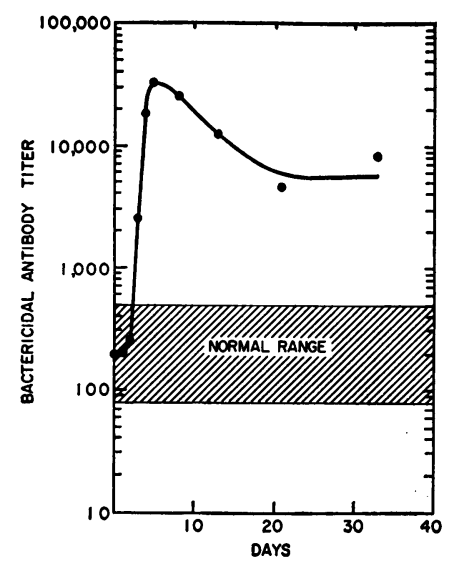

Fig. 3. Development and Decline of Bactericidal ANTIBODY TITER FOLLOWING A SINGLE INJECTION OF 0.25 $\mu G$ of ENDotoxin. Data derived from pooled sera and expressed as the reciprocals of the titers.

after a single injection of endotoxin (20). Antibody titers consistently attained maximal values at day 5 ; thereafter a progressive decline occurred which by day 18 to 22 stabilized at approximately $20 \%$ of the maximal titer (Figure 3 ). Comparison of the titers with the febrile response of the same animals (Table II) discloses no correlation between this antibody and the tolerance displayed. Thus, no antibody above base-line activity was demonstrable at the time refractoriness was maximal (24 hours). Furthermore, while levels of antibody were rapidly increasing during the next
4 days (Figure 3 ), refractoriness declined appreciably. Finally, reduced but significant tolerance was maintained for at least 34 days, during which time further significant changes in antibody levels had occurred.

Failure to demonstrate an "anamnestic" response. A single injection of endotoxin has been reported as inducing an accelerated return of the tolerant state $(21,22)$. Recently confirmation of this effect in rabbits was alluded to as an "anamnestic" response (23). To investigate the role of antibody in this event, groups of animals given nine daily injections of $0.25 \mu \mathrm{g}$ of endotoxin were later challenged with the same dose; these animals were then given another injection of $0.25 \mu \mathrm{g} 24$ or 48 hours later (Table III). Identical studies were simultaneously performed on normal animals. Antibody levels were determined on sera obtained immediately before each challenge (Table III). The data show that a single injection of endotoxin produces within 1 day a marked increase in resistance to challenge in both normal and tolerant rabbits. Although the latter were more refractory to challenge ( $p<0.02, t$ test) at this time, the percentage change of the mean FI was essentially the same for both groups ( $51 \%$ vs. $54 \%$ decrease, respectively). When the interval between the two challenge injections was extended to 48 hours, the febrile response of the previously

TABLE III

Aitempts to elicit an "anamnestic" response in rabbits previously rendered tolerant to endotoxin

\begin{tabular}{|c|c|c|c|c|c|}
\hline \multirow[b]{2}{*}{ Status } & \multirow{2}{*}{$\begin{array}{l}\text { No. of } \\
\text { rabbits } \\
\text { tested }\end{array}$} & \multirow{2}{*}{$\begin{array}{l}\text { Time of } \\
\text { bleeding* and } \\
\text { challenge }\end{array}$} & \multirow{2}{*}{$\underset{\text { index }}{\text { Fevert }}$} & \multicolumn{2}{|c|}{ Antibody titer $\ddagger$} \\
\hline & & & & Bentonite & Bactericidal \\
\hline $\begin{array}{c}\text { Normal } \\
1 \S \\
2 \S\end{array}$ & $\begin{array}{l}44 \\
20 \\
16\end{array}$ & $\begin{array}{c}\text { hours } \\
0 \\
24 \\
48\end{array}$ & $\begin{array}{c}\mathrm{cm}^{2} \\
48.6 \pm 1.3 \\
23.7 \pm 2.9 \\
40.2 \pm 2.6\end{array}$ & $\begin{array}{l}<2 \\
<2 \\
<2\end{array}$ & $\begin{array}{l}<500 \\
<500 \\
<500\end{array}$ \\
\hline $\begin{array}{l}\text { Tolerant } \\
10 \|\end{array}$ & 4 & $\begin{array}{r}0 \\
48\end{array}$ & $\begin{array}{l}33.1 \pm 3.1 \\
17.2 \pm 6.8\end{array}$ & $\begin{array}{r}128 \\
64\end{array}$ & $\begin{array}{r}100,000 \\
<75,000\end{array}$ \\
\hline $33 \|$ & 5 & $\begin{array}{r}0 \\
24\end{array}$ & $\begin{array}{l}36.5 \pm 4.2 \\
16.7 \pm 1.6\end{array}$ & $\begin{array}{r}128 \\
32\end{array}$ & $\begin{array}{l}30,000 \\
25,000\end{array}$ \\
\hline $56 \|$ & 6 & $\begin{array}{r}0 \\
24\end{array}$ & $\begin{array}{l}27.1 \pm 4.5 \\
13.8 \pm 1.1\end{array}$ & $\begin{array}{l}64 \\
32\end{array}$ & $\begin{array}{l}15,000 \\
10,000\end{array}$ \\
\hline
\end{tabular}

* All animals bled and injected with $0.25 \mu \mathrm{g}$ at 0 time. Twenty-four or 48 hours later animals were bled and challenged again.

$\dagger$ Mean \pm standard error.

I Data derived from pooled sera and expressed as reciprocals of the titers.

$\$$ Days between initial and challenge injections.

II Days af ter the last of nine daily injections of endotoxin. 
tolerant group ( $F I=17.2)$ again was significantly less than the normals $(F I=40.2, \mathrm{p}<0.01)$; however, the percentage decrease from their respective original values (i.e., 48 hours before) was different $(51 \%$ and $17 \%$ decreases in FI, respectively). Despite the marked alteration in febrile reactivity of both normal and tolerant animals and the presence of high levels of circulating antibody in the latter groups, the antigenic stimulus of a second injection of endotoxin did not further increase the antibody titers (Table III).

\section{Discussion}

Although endotoxin tolerance has been extensively investigated, most workers have concerned themselves primarily with the phase of maximal resistance. In the present work, it was advantageous to determine the duration of this effect. The prevailing view has been that once established, febrile tolerance disappears within 2 to 3 weeks after a series of endotoxin injections; however, some authors obtained evidence to the contrary, viz., rabbits given endotoxin 3 months after induction of tolerance were found to show a delay in the initial rise in temperature such as was seen in tolerant animals (22); in some human volunteers tolerance was manifested for as long as 17 weeks (21). The present findings of a significant degree of refractoriness at 63 days attest to and extend the evidence for persistence. In retrospect the persistence of this altered response to endotoxin might have been anticipated, since it has been reported that 5 weeks after a series of injections there remained an enhanced rate of clearance of $\mathrm{Cr}^{51}$-labeled endotoxin (24), and protection against the lethal effect of endotoxin has been transferred with the serum of mice that had received a single injection 21 days earlier (7).

The experiments with two markedly different schedules for inducing resistance emphasize the arbitrary character of the means for eliciting tolerance. The reduction in febrile response and the persistence of tolerance following the series of injections were not significantly different from that elicited by a single injection. The differences in the levels of antibody developed were not unexpected, since this is known to depend on the amount of antigen administered (20). Differences in the antibody response developed by single or multiple injections appeared to be of a quantitative rather than qualitative character.

There are many variables that could conceivably influence the characteristics of the refractory state. Among these factors are the wide variations in pyrogenic potency of endotoxin preparations, schedule of injections, size of the challenge dose, differences in species, and prior exposure to endotoxin. Inasmuch as similar data were obtained with both $E$. coli and $S$. enteritidis endotoxins, this variable did not appear to be a factor. The use of a range of doses of endotoxin revealed the extent to which the challenge dictates the outcome, e.g., if rabbits are challenged with doses evoking maximal responses, tolerance is found to be transitory (Figure 1). This may account for the brief duration of tolerance reported by others. On the other hand, some workers, employing different preparations, have reported the rapid disappearance of tolerance (25). It should be noted that the dose range they used did not evoke maximal responses, thus emphasizing that factors associated with the product may be as important as the dose.

The view that humoral factors contribute to or account for tolerance to the febrile effects of endotoxin is once again receiving support $(8,9)$. The increasing conviction that antibodies (opsonins) are the humoral factors responsible for refractoriness to endotoxin derives from passive transfer experiments which in themselves do not constitute proof that antibody is necessarily the responsible component. It has recently been reported that "antibodies of the $19 \mathrm{~S}$ class," in the form of fractions of serum from tolerant animals, are the factors that transfer tolerance (26). It should be noted that this preliminary report did not provide information on either the effect of transfer of similar fractions from normal rabbit serum or on antibody measurements. The fact is that despite recent frequent allusions to immune mechanisms being operative in endotoxin tolerance, no quantitative data on specific antibodies have been reported. There can, however, be little doubt that humoral factors are present in tolerant sera as attested to by the passive transfer experiments; nevertheless, these humoral factors are not necessarily antibodies.

In the present work the levels of antibody developed in response to a series of injections of en- 
dotoxin were assessed by procedures that differ appreciably in their capacity to detect different immunoglobulins (11). The serologic data obtained, nonetheless, show a similar pattern and a seeming lack of correlation with either the development, or persistence, of febrile tolerance. It is noteworthy, however, that during the first few days following the series of endotoxin injections, there occur a concomitant decline in levels of serum antibody and a marked decrease in tolerance. After this initial decrease in refractoriness, a significant and relatively constant degree of tolerance remains, whereas levels of antibody decline and later plateau. It may very well be that the amount of antibody required for the maintenance of tolerance is considerably less than that measured as circulating antibody, or that a more subtle qualitative change may be responsible. Such an interpretation could account for the persistence of tolerance inasmuch as the levels of circulating antibody, although reduced from the initial peak, were still far above background. Even at the termination of the experiment the serum level of precipitating antibody was at least $60 \mu \mathrm{g}$ of antibody protein per $\mathrm{ml}$; thus, the antibody in as little as $1 \mathrm{ml}$ of serum should be sufficient to complex the entire challenge (20). It is possible that only a minute proportion of the challenge dose escapes and reaches key target cells triggering off the febrile reaction; then again endotoxin, even when complexed with antibody, may retain pyrogenic capabilities.

The type of antibody produced in response to endotoxin is predominately a $19 \mathrm{~S}$ macroglobulin; however, the $7 \mathrm{~S}$ antibody that develops, although a small proportion of the total, might nonetheless account for the observation of a slower decline in precipitating antibody levels, since it is known to be the more avid form of specific antibody (27). In contrast to other antigens that have been studied, the onset of production of significant $7 \mathrm{~S}$ antibody (24 days) seemed not to affect the continuing high levels of the $19 \mathrm{~S}$ bactericidal antibody. In seeking to explain the latter findings, it should be noted that the series of daily intravenous injections generally employed to evoke tolerance represents a departure from the usual methods of antigenic stimulation. This may be important in that the same amount of antigen given as a single injection has been found to give rise to essentially
$19 \mathrm{~S}$ antibody (28). Although it has been possible to produce significant amounts of $7 \mathrm{~S}$ antibodies to this kind of antigen in the rabbit (11), massive doses $(1,500 \mu \mathrm{g})$ were used in comparison to that employed to induce tolerance $(2.25 \mu \mathrm{g})$.

A rapidly developing resistance to endotoxin has been previously noted for various host effects such as fever (19), lethality (7), and resistance to infection (29). Indeed, the present work shows that following a single injection of endotoxin, tolerance developed so rapidly it had reached a maximum at least 48 hours before any increase in antibody levels was discernible. Despite the abrupt rise in serum antibody that occurred at day 3 and reached a peak at day 5 , the diminished febrile response remained constant; no significant changes in the degree of tolerance took place during the following 30 days even though the level of antibody had declined.

As noted previously, following lapse of tolerance, a rapid return of the refractory state ensued upon rechallenge $(21,22)$. Significant febrile tolerance was still demonstrable in our rabbits at the time the experiments were terminated; another injection on the following day sufficed to restore the original high level of resistance. However, rapid reduction in febrile response could also be evoked in normal animals. On the other hand, if the challenge dose was administered 48 hours later, significantly greater refractoriness was noted in the tolerant group. Tolerance that reappeared within 2 days in rabbits whose refractoriness had lapsed was described as an "anamnestic" response (23). In the absence of antibody measurements, the inference that immune mechanisms were responsible for this effect is not warranted. If this rapid return of tolerance is to be equated with an anamnestic response, as this designation is generally applied to immune systems, there should occur a prompt and sharp rise in serum antibody levels. In the work reported here no such effects were observed; in three experiments no elevation in titer of circulating antibody was evident at the time when the animals displayed "reactivated" tolerance.

These studies and earlier work have failed to demonstrate a correlation between titers of the $19 \mathrm{~S}$ antibody and tolerance. It should be noted that humoral factors other than the immunoglobulins may also be involved. We have found that 
6-mercaptopurine administered at the same time as the endotoxin injections, to a large extent, suppressed the production of specific antibody; titers were approximately $10 \%$ of those seen in controls (30). Despite this profound reduction of specific antibody levels, the "suppressed" and control animals developed febrile tolerance of equal magnitude (31). These findings fail to support the idea that some macroglobulin antibody, different from the familiar one directed against the somatic polysaccharide, is the major factor in resistance (26). In view of the well-documented opsonic capabilities of the antipolysaccharide macroglobulin antibody, it does not seem justifiable at this time to ignore this immunoglobulin as a factor in tolerance. Finally, it is emphasized that these antibodies, which are invariably present in all normal animals, are far more prominent in the endotoxin-treated host. In all probability they interact with the intravenously injected endotoxin; they could therefore participate in its more efficient clearance, which is such a distinctive feature of tolerance.

\section{Summary}

Febrile tolerance was induced in rabbits by a series of nine daily intravenous injections of Salmonella enteritidis endotoxin, and at varying intervals thereafter the animals were tested quantitatively for resistance to the pyrogenic activity of this bacterial polysaccharide. Utilizing a 1,000fold range of challenge doses, we found that refractoriness to the least amount of endotoxin employed $(0.25 \mu \mathrm{g})$ persisted for more than 8 weeks, and tolerance to endotoxin in increasing amounts was of progressively shorter duration. During the period of diminished febrile response, there was no consistent correlation with the levels of circulating antibody as measured by five different techniques.

In animals whose resistance had diminished, tolerance was "reactivated" within 24 hours by a single injection, during which time no increase in antibody was discernible. The immune response to the tolerance schedule of multiple injections of endotoxin involved the development and persistence of substantial levels of macroglobulin antibody; however, after 3 weeks or more, small amounts of $7 \mathrm{~S}$ antibody were also evident.
A single injection of endotoxin evoked within 24 hours pyrogenic tolerance of a magnitude similar to that following multiple injections; this tolerance persisted at diminished levels for at least 34 days. However, specific antibody was not detected before 72 hours, attained a maximum at 5 days, and declined thereafter.

\section{Acknowledgments}

It is a pleasure to acknowledge the expert technical assistance of Messrs. S. B. Ward, J. Edelin, and F. J. Koczot. The purified endotoxin derived from $S$. enteritidis was kindly provided by Dr. E. Ribi. The authors are indebted to Dr. D. W. Alling for the statistical analyses.

\section{References}

1. Mulholland, J. H., S. M. Wolff, A. L. Jackson, and M. Landy. Studies on a temporal relationship between pyrogenic tolerance and levels of antibody to endotoxin. Fed. Proc. 1964, 23, 565.

2. Bennett, I. L., Jr., and L. E. Cluff. Bacterial pyrogens. Pharmacol. Rev. 1957, 9, 427.

3. Morgan, H. R. Immunologic properties of an antigenic material isolated from Eberthella typhosa. J. Immunol. 1941, 41, 161.

4. Morgan, H. R. Resistance to the action of the endotoxins of enteric bacilli in man. J. clin. Invest. 1948, 27, 706.

5. Beeson, P. B. Tolerance to bacterial pyrogens. I. Factors influencing its development. J. exp. Med. 1947, 86, 29.

6. Beeson, P. B. Tolerance to bacterial pyrogens. II. Role of the reticulo-endothelial system. J. exp. Med. 1947, 86, 39.

7. Creech, H. J., R. F. Hankwitz, Jr., and D. R. A. Wharton. Further studies of the immunological properties of polysaccharides from Serratia marcescens (Bacillus prodigiosus). I. The effects of passive and active immunization on the lethal activity of the polysaccharides. Cancer Res. 1949, 9, 150.

8. Freedman, H. H. Passive transfer of tolerance to pyrogenicity of bacterial endotoxin. J. exp. Med. 1960, 111, 453.

9. Greisman, S. E., F. A. Carozza, Jr., and J. D. Hills. Mechanisms of endotoxin tolerance. I. Relationship between tolerance and reticuloendothelial system phagocytic activity in the rabbit. J. exp. Med. 1963, 117, 663.

10. Wolff, S. M., J. H. Mulholland, and S. B. Ward. Quantitative aspects of the pyrogenic response of rabbits to endotoxin. J. Lab. clin. Med. 1965, 65, 268.

11. Weidanz, W. P., A. L. Jackson, and M. Landy. Some aspects of the antibody response of rabbits to immunization with enterobacterial somatic anti- 
gens. Proc. Soc. exp. Biol. (N. Y.) 1964, 116, 832.

12. Michael, J. G., and F. S. Rosen. Association of "natural". antibodies to gram-negative bacteria with the $\gamma_{1}$-macroglobulins. J. exp. Med. 1963, 118, 619.

13. Ribi, E., W. T. Haskins, M. Landy, and K. C. Milner. Preparation and host-reactive properties of endotoxin with low content of nitrogen and lipid. J. exp. Med. 1961, 114, 647.

14. Weidanz, W. P., and M. Landy. A simplified method for bactericidal assay of natural antibodies against gram-negative bacteria. Proc. Soc. exp. Biol. (N. Y.) 1963, 113, 861.

15. Wolff, S. M., S. B. Ward, and M. Landy. Serologic properties of bentonite particles coated with microbial polysaccharides. Proc. Soc. exp. Biol. (N. Y.) 1963, 114, 530.

16. Lowry, O. H., N. J. Rosebrough, A. L. Farr, and R. J. Randall. Protein measurement with the Folin phenol reagent. J. biol. Chem. 1951, 193, 265.

17. Flodin, P., and J. Killander. Fractionation of humanserum proteins by gel filtration. Biochim. biophys. Acta (Amst.) 1962, 63, 403.

18. Martin, R. G., and B. N. Ames. A method for determining the sedimentation behavior of enzymes: application to protein mixtures. J. biol. Chem. 1961, 236, 1372.

19. Grant, R. Refractoriness to pyrogens. Effects of incubation of pyrogen with plasma from normal and refractory donors on the responses of refractory recipients. Amer. J. Physiol. 1953, 173, 246.

20. Landy, M., A. G. Johnson, M. E. Webster, and J. F. Sagin. Studies on the $\mathrm{O}$ antigen of Salmonella typhosa. II. Immunological properties of the purified antigen. J. Immunol. 1955, 74, 466.

21. Neva, F. A., and H. R. Morgan. Tolerance to the actions of endotoxins of enteric bacilli in patients convalescent from typhoid and paratyphoid fevers. J. Lab. clin. Med. 1950, 35, 911.
22. Farr, R. S., S. L. Clark, Jr., J. E. Proffitt, and D. H. Campbell. Some humoral aspects of the development of tolerance to bacterial pyrogens in rabbits. Amer. J. Physiol. 1954, 177, 269.

23. Watson, D. W., and Y. B. Kim. Modification of host responses to bacterial endotoxins. I. Specificity of pyrogenic tolerance and the role of hypersensitivity in pyrogenicity, lethality, and skin reactivity. J. exp. Med. 1963, 118, 425.

24. Carey, F. J., A. I. Braude, and M. Zalesky. Studies with radioactive endotoxin. III. The effect of tolerance on the distribution of radioactivity after intravenous injection of Escherichia coli endotoxin labeled with $\mathrm{Cr}^{\text {rt }}$. J. clin. Invest. 1958, 37, 441.

25. Cluff, L. E. Studies of the effect of bacterial endotoxins on rabbit leukocytes. II. Development of acquired resistance. J. exp. Med. 1953, 98, 349.

26. Kim, Y. B., and D. W. Watson. Passive transfer of pyrogenic tolerance to bacterial endotoxins with fractions containing $19 \mathrm{~S}$ antibodies. Bact. Proc. 1964, 44.

27. Stelos, P., and D. W. Talmage. The separation by starch electrophoresis of two antibodies to sheep red cells differing in hemolytic efficiency. $\mathrm{J}$. infect. Dis. 1957, 100, 126.

28. Landy, M., A. L. Jackson, and R. Sanderson. Humoral and cellular aspects of the immune response to the somatic antigen of Salmonella enteritidis. To be published.

29. Rowley, D. Stimulation of natural immunity to Escherichia coli infections. Observations on mice. Lancet 1955, 1, 232.

30. Wolff, S. M., J. H. Mulholland, and M. Rubenstein. Suppression of the immune response to bacterial endotoxins in Bacterial Endotoxins, M. Landy and W. Braun, Eds. New Brunswick, Rutgers University Press, 1964.

31. Wolff, S. M., J. H. Mulholland, M. Rubenstein, and P. D. Mott. Effect of 6-mercaptopurine on endotoxin tolerance. Clin. Res. 1964, 12, 455. 